\title{
ANALISIS SAINS SEBAGAI CARA BERPIKIR PADA BUKU TEMATIK SISWA
} KELAS V SD

\author{
Siti Sholiha Nurfaidah ${ }^{1}$, Azis Lukman Praja², Moh. Nurhadi ${ }^{3}$ \\ 1,2,3PGSD FKIP Universitas Pasundan \\ 1sitinurfanurfaidah@unpas.ac.id, 2azisunpas@gmail.com, 3mnurhadi@unpas.ac.id
}

\begin{abstract}
Literacy of science is very important to be mastered by each individual to be able to adapt to the progress of science and technology in the future. One attempt to improve the ability of science literacy through the analysis of textbooks lessons. The type of research used is descriptive, by collecting data in the form of documentation study. The sample in this research is several pages of analyzed books taken in a random way using multistage sampling technique. The results show $21 \%$ of the book presents the aspect of science as a way of thinking. The aspect is presented on the entire theme of the book with various values. In themes 1 and 2 this aspect is often presented that is equal to $71 \%$, and $51 \%$. The following findings show that Book $Y$ simply presents aspects of science as a way of thinking. In other words, Book $Y$ is enough to emphasize material that supports the mastery of the process.
\end{abstract}

Keywords: science literacy; way of thinking; analysis of textbooks.

\begin{abstract}
ABSTRAK
Literasi sains sangat penting untuk dikuasai oleh setiap individu untuk dapat beradaptasi dengan kemajuan ilmu pengetahuan dan teknologi di masa mendatang. Salah satu upaya untuk meningkatkan kemampuan literasi sains melalui analisis buku teks pelajaran. Jenis penelitian yang digunakan adalah deskriptif, dengan mengumpulkan data berupa studi dokumentasi. Sampel pada penelitian ini adalah beberapa halaman buku yang dianalisis yang diambil dengan cara acak menggunakan teknik multistage sampling. Hasil menunujukkan $21 \%$ buku menyajikan aspek sains sebagai cara berpikir. Adapun aspek ini disajikan pada seluruh tema buku tersebut dengan nilai yang beragam. Pada tema 1 dan 2 aspek ini sering disajiakan yaitu sebesar $71 \%$, dan $51 \%$. Temuan berikut menunjukkan bahwa Buku $Y$ cukup menyajikan aspek sains sebagai cara berpikir. Dengan kata lain Buku $Y$ ini cukup menekankan materi yang menunjang pada penguasaan proses.
\end{abstract}

Kata kunci: literasi sains; cara berpikir; analisis buku teks pelajaran

\section{A. Pendahuluan}

Menurut Tasakorn \& Pongtabodee literasi sains sangat penting untuk dikuasai oleh setiap individu (Erdoğan \& Köseoğlu, 2012). PISA 2000 dan
2003 mendefinisikan literasi sains sebagai kapasitas untuk menggunakan pengetahuan dan kemampuan ilmiah, mengidentifikasi pertanyaan-pertanyaan dan menarik 
kesimpulan berdasarkan bukti dan data yang ada agar dapat memahami alam semesta dan membantu untuk membuat keputusan dari perubahan yang terjadi akibat interaksi manusia dengan alamnya. Dengan demikian, literasi sains dapat diartikan sebagai kemampuan yang berhubungan dengan penggunaan ilmu pengetahuan dan teknologi dalam menjalankan kehidupan dan memecahkan permasalahan pada masyarakat modern yang kental dengan kemajuan sains dan teknologi.

Penguasaan literasi sains tidak dapat dimunculkan begitu saja dalam waktu yang singkat, tetapi membutuhkan waktu yang cukup panjang untuk pembentukannya. Salah satu langkah untuk membentuk kemampuan sains adalah melalui pendidikan, khususnya pembelajaran sains. Hal-hal yang berkaitan dengan literasi sains, sudah semestinya dilibatkan dalam seluruh aspek yang terkait dengan proses pembelajaran agar kemampuan literasi sains dapat dikuasai oleh siswa. Melalui penguasaan literasi sains diharapkan dapat mempermudah siswa-siswa di Indonesia untuk beradaptasi dengan kemajuan ilmu pengetahuan dan teknologi di masa mendatang

Namun disayangkan, pentingnya literasi sains tidak berbanding lurus dengan pengusaan siswa Indonesia akan literasi sains. Hasil penilaian internasional, Programme for Internasional Student Assesment (PISA) menunjukkan kondisi literasi sains Indonesia saat ini masih sangat rendah dibandingkan dengan negara lainnya. Berikut ini adalah perolehan nilai literasi sains siswa Indonesia.

Tabel 1 Fakta Literasi Sains Peserta Didik Indonesia 200-2015

\begin{tabular}{c|l|l} 
Tahun & Skor & \multicolumn{1}{c}{ Peringkat } \\
\hline $\mathbf{2 0 0 0}$ & 393 & $38 / 41$ \\
\hline $\mathbf{2 0 0 3}$ & 395 & $38 / 40$ \\
\hline $\mathbf{2 0 0 6}$ & 393 & $50 / 57$ \\
\hline $\mathbf{2 0 0 9}$ & 383 & $60 / 65$ \\
\hline $\mathbf{2 0 1 2}$ & 375 & $64 / 65$ \\
\hline $\mathbf{2 0 1 5}$ & 403 & $64 / 75$ \\
\hline Sumber: Harian Kompas, 2015
\end{tabular}

Berdasarkan tabel di atas diketahui bahwa sejak 2000 sampai dengan tahun 2015 rata-rata nilai literasi sains siswa Indonesia adalah 391,5 yang menempatkan Indonesia pada peringkat 8 sampai 2 terbawah dari 40-75 negara. Sebagaimana diungkapkan dalam laporan Firman (2007) bahwa tingkat penguasaan literasi sains peserta didik usia 15 tahun di Indonesia adalah rendah. 
Pada tingkat kemampuan ini, siswa Indonesia pada umumnya dinilai hanya akan mampu mengingat fakta, istilah, dan hukum-hukum ilmiah serta menggunakannya dalam menarik kesimpulan ilmiah yang sederhana (Yusuf, 2004 dalam Amalia, 2009).

Fakta nilai literasi sains yang rendah menjadi daya tarik tersendiri untuk mengkaji faktor yang mempengaruhi tingkat literasi sains. Salah satunya adalah buku teks pelajaran yang merupakan bagian terdekat dan berkaitan secara langsung dengan siswa. Peraturan Menteri Pendidikan Nasional Nomor 2 Tahun 2008 pasal 1 ayat 3 (Depdiknas, 2008), menyatakan:

Buku teks pelajaran (textbook) adalah buku acuan wajib untuk digunakan di satuan pendidikan dasar dan menengah atau perguruan tinggi yang memuat materi pembelajaran dalam rangka peningkatan keimanan, ketakwaan, akhlak mulia, dan kepribadian, penguasaan ilmu pengetahuan dan teknologi, peningkatan kepekaan dan kemampuan estetis, peningkatan kemampuan kinestetis dan kesehatan yang disusun berdasarkan standar nasional pendidikan.

Berdasarkan uraian Depdiknas di atas, buku teks pelajaran digunakan sebagai acuan wajib untuk dipergunakan dalam proses pembelajaran. Dengan kata lain, proses pembelajaran yang berlangsung tidak terlepas dari hal-hal yang dimuat di dalam buku tersebut. Buku teks pelajaran merupakan perwujudan dari kurikulum dan kompetensi yang ingin dicapai oleh siswa, Selain itu buku teks pelajaran berkontribusi pada pengembangan kompetensi siswa dalam mengaplikasikan pengetahuan sains yang dimilikinya. Makadari itu, buku teks pelajaran yang memuat aspek literasi sains akan berpengaruh terhadap pengembangan kompetensi dan peningkatan literasi sains siswa (Riadiyani, 2009). Oleh karena itu, penelitian terhadap kondisi buku teks pelajaran yang saat ini beredar di lapangan sangat penting untuk dilakukan, terutama yang berhubungan dengan literasi sains.

Penelitian tentang buku teks pelajaran telah banyak dilakukan di Indonesia, baik berdasarkan kurikulum, tingkat keterbacaan, kelayakan isi, kandungan keterampilan proses dan sebagainya. Namun, penelitian buku teks pelajaran yang memuat aspekaspek literasi sains masih jarang 
dilakukan. Sebagaimana penelitian terdahulu dilakukan di jenjang pendidikan SMA dan SMP (Amalia, 2009; Lahiriah, 2008; Riadiyani, 2009; Rusyati, 2009; Sandi, 2013; dan Utami, 2008), dan Nurfaidah (2014 dan 2017) melakukan penelitian serupa pada jenjang SD.

Adapun kebijakan penetapan implementasi kurikulum 2013 berdampak pada berbagai perubahan. Perubahan terbesar banyak dirasakan pada jenjang sekolah dasar, tidak terkecuali pada buku yang berlaku. Materi yang dipelajari tidak lagi dikelompokkan kepada beberapa mata pelajaran. Melainkan diintegrasikannya beberapa materi yang berkaitan (seperti IPA, IPS, Bahasa Indonesia, PKn dan SBdP) menjadi satu tema pembelajaran. Hal inilah yang menjadikan penelitian terhadap buku tematik siswa penting untuk dilakukan. Karena perlu diketahui bagaimana gambaran literasi sains pada buku yang berlaku saat ini.

Tujuan dalam penelitian kali ini yaitu untuk mendapatkan informasi mengenai penyajian literasi sains pada setiap tema dan pada keseluruhan buku tematik siswa SD
Kelas $\mathrm{V}$ yang mencakup aspek sains sebagai cara berpikir. Hasil penelitian ini diharapkan dapat memberikan manfaat untuk berbagai pihak, diantaranya sebagai berikut: 1) Bagi penulis buku teks pelajaran. Hasil penelitian ini dapat dijadikan sebagai bahan pertimbangan untuk penulisan buku teks pelajaran yang bermutu berdasarkan literasi sains. 2) Bagi peneliti lain. Hasil penelitian ini dapat dijadikan bahan pertimbangan untuk pelaksanaan penelitian selanjutnya, baik sebagai rujukan, dukungan, maupun pembanding mengenai konsep literasi sains. 3) Bagi pemerintah. Hasil penelitian ini dapat dijadikan sebagai bahan pertimbangan dalam menetapkan suatu kebijakan tentang pedoman ketentuan membuat buku teks pelajaran yang layak digunakan di sekolah.

\section{B. Metode Penelitian}

Populasi pada penelitian ini adalah semua materi pada buku tematik siswa kelas $\mathrm{V}$ yang dianalisis. Buku ini kemudian dinyatakan sebagai buku Y. Adapun sampel pada penelitian ini adalah 66 halaman pada buku yang dianalisis yang diambil dengan cara acak. Sampel diambil 
dengan teknik multistage sampling (penarikan sampel beberapa tahap). Adapun pada penelitian ini digunakan teknik penarikan sampel 3 tahap, sebagai berikut: Tahap 1: Pemilihan Tema. Tema yang dianalisis diambil sebanyak $50 \%$ dari seluruh jumlah tema yang ada pada buku yang dianalisis. Tahap 2: Pemilihan Subtema. Subtema yang dianalisis diambil sebanyak $30 \%$ dari seluruh jumlah subtema yang ada pada setiap tema yang dipilih. Tahap 3: Pemilihan Halaman. Halaman yang dianalisis diambil sebanyak $30 \%$ dari seluruh jumlah halaman yang ada pada setiap subtema yang dipilih. Hal ini diadaptasi dari Journal of research in science teaching (Chiappetta, Fillman \& Sethna, 1993). Adapun pengambilan sampel halaman buku $Y$ lebih rinci ditunjukkan pada tabel berikut.

\begin{tabular}{|c|c|c|c|c|}
\hline Buku & $\begin{array}{l}\text { Te- } \\
\text { ma } \\
(50 \\
\%)\end{array}$ & $\begin{array}{l}\text { Sub } \\
\text { Te- } \\
\text { ma } \\
(30 \\
\%)\end{array}$ & $\begin{array}{l}\sum_{\text {Total }} \\
\text { Hala- } \\
\text { man }\end{array}$ & $\begin{array}{l}\sum_{\text {Halaman }} \\
\text { yang } \\
\text { Diidenti- } \\
\text { fikasi } \\
(30 \%)\end{array}$ \\
\hline \multirow{5}{*}{$\begin{array}{c}\text { Tema- } \\
\text { tik } \\
\text { Kelas } \\
\text { V SD }\end{array}$} & 1 & 1 & 64 & 19 \\
\hline & 2 & 3 & 34 & 10 \\
\hline & 4 & 2 & 39 & 11 \\
\hline & 6 & 2 & 42 & 13 \\
\hline & 8 & 3 & 44 & 13 \\
\hline Total & $\begin{array}{l}5 \\
\text { tem } \\
\text { a }\end{array}$ & $\begin{array}{l}5 \\
\text { sub- } \\
\text { tem } \\
\text { a }\end{array}$ & $\begin{array}{l}223 \\
\text { hal }\end{array}$ & 66 hal \\
\hline
\end{tabular}

Jenis penelitian yang digunakan dalam penelitian ini adalah penelitian deskriptif dengan metode dokumentasi atau metode analisis dokumen. Dalam menggunakan metode dokumentasi, peneliti memegang check-list untuk mencari variabel yang sudah ditentukan. Data yang diperoleh kemudian diolah dengan menghitung jumlah dan persentase penyajian indikator literasi sains pada aspek sains sebagai cara berpikir untuk setiap tema pada buku ajar yang digunakan.

Instrumen yang digunakan sebagai alat untuk mengumpulkan data yang diperlukan yaitu lembar analisis yang berisi indikator literasi sains yang diadopsi dari Chiappetta et all. (1991a dalam Amelia, 2009; Cansiz \& Turker, 2011; Chabalengula et al., 2008; Lahiriah, 2008; Riadiyani, 2009; Rusyati, 2009; Sandi, 2013; Nurfaidah, 2014). Namun pada penelitian kali ini hanya mengungkap salah satu aspek literasi sains, yaitu sains sebagai cara berpikir.

\section{C.Hasil Penelitian dan Pembahasan}

Buku yang dianalisis adalah satu buku tematik siswa kelas V SD yang digunakan sebagai penunjang 
kurikulum 2013 di sekolah. Lima dari sembilan tema pada buku ini dipilih untuk dianalisis, diantaranya: 1) Benda-benda di Lingkungan (tema 1); 2) Peristiwa dalam Kehidupan (tema 2); 3) Sehat itu Penting (tema 4); 4) Organ Tubuh Manusia dan Hewan (tema 6); 5) Ekosistem (tema 8). Jumlah halaman buku yang dianalisis pada penelitian ini adalah 66 halaman yaitu seluruh paragraf materi yang dimuat dalam buku tersebut, kecuali halaman yang hanya mengandung pertanyaan ulasan dan kosakata, serta pencantuman tujuan dan sasaran pembelajaran.

Kriteria yang digunakan untuk menganalisis buku diadopsi dari jurnal penelitian pendidikan yang ditulis oleh Chiappetta et al (Amelia, 2009; Chabalengula et al., 2008; Lahiriah, 2008; Riadiyani, 2009; Rusyati, 2009; Sandi, 2013; Nurfaidah, 2014; Nurfaidah, 2017), dikelompokkan menjadi empat aspek literasi sains, yaitu: 1) Aspek pengetahuan sains; 2) Aspek sains sebagai cara menyelidiki; 3) Aspek sains sebagai cara berpikir; dan 4) Aspek interaksi sains, teknologi dan masyarakat. Adapun ciri materi pada buku $Y$ yang termasuk aspek sains sebagai cara berpikir (aspek literasi sains yang diteliti) dapat diidentifikasi melalui indikator berikut: a) Menggambarkan bagaimana seorang ilmuwan melakukan eksperimen; b) Menunjukkan perkembangan historis dari sebuah ide; c) Menekankan sifat empiris dan objektivitas ilmu sains; d) Mengilustrasikan penggunaan asumsi-asumsi; e) Menunjukkan bagaimana ilmu sains berjalan dengan pertimbangan induktif dan deduktif; f) Memberikan hubungan sebab dan akibat; g) Mendiskusikan fakta dan bukti; dan h) Menyajikan metode ilmiah dan pemecahan masalah.

Berikut ini, merupakan gambaran literasi sains aspek sains sebagai cara berpikir pada buku $\mathrm{Y}$.

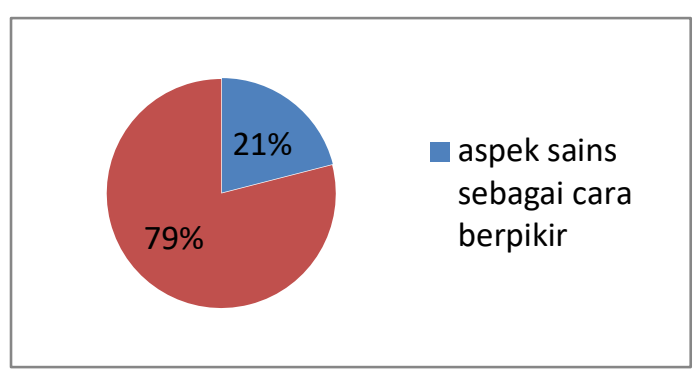

Gambar 1. Persentase Rata-rata Penyajian Aspek Sains Literasi Sains pada Buku Y 
Gambar 1 menunjukkan aspek sains sebagai cara berpikir jarang disajikan pada keseluruhan buku yang dianalisis, yaitu sebesar $21 \%$. Adapun pada setiap tema buku $Y$ aspek ini disajikan sebagai berikut.

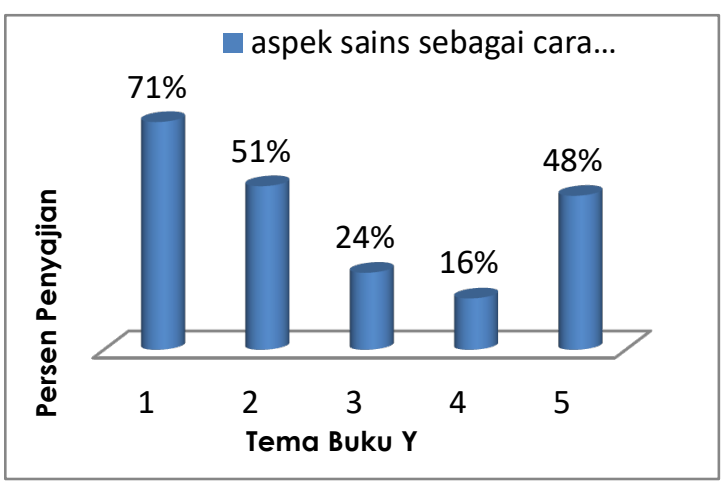

Gambar 2. Persentase Penyajian Aspek Sains sebagai Cara Berpikir pada Setiap

Berdasarkan Gambar 2 di atas, dapat dilihat bahwa pada setiap tema dari buku $Y$ menyajikan aspek sains sebagai cara berpikir yang beragam. Aspek ini sering disajikan pada tema 1 dan 2 dengan materi Benda-benda di Lingkungan dan Peristiwa dalam Kehidupan, yaitu sebesar $71 \%$ dan $51 \%$. Sedangkan pada tema 3, 4 dan 5 aspek ini masih jarang disajikan, terutama pada tema 4 sebesar $16 \%$. Adapun data yang menunjukkan penyajian indikator literasi sains aspek sains sebagai cara berpikir pada Buku $\mathrm{Y}$, adalah sebagai berikut.
Tabel 3. Penyajian Indikator Literasi Sains Aspek Sains sebagai Cara Berpikir Indikator Literasi Sains $\Sigma \quad \%$ Aspek Sains sebagai

Cara Berpikir

\begin{tabular}{|c|c|c|}
\hline $\begin{array}{l}\text { Menggambarkan } \\
\text { bagaimana } \quad \text { seorang } \\
\text { ilmuwan melakukan } \\
\text { eksperimen. }\end{array}$ & 0 & 0 \\
\hline $\begin{array}{l}\text { Menunjukkan } \\
\text { perkembangan historis } \\
\text { dari sebuah ide. }\end{array}$ & 11 & 5 \\
\hline $\begin{array}{l}\text { Menekankan sifat } \\
\text { empiris dan objektivitas } \\
\text { ilmu sains. }\end{array}$ & 9 & 4 \\
\hline $\begin{array}{l}\text { Mengilustrasikan } \\
\text { penggunaan asumsi- } \\
\text { asumsi. }\end{array}$ & 6 & 3 \\
\hline $\begin{array}{l}\text { Menunjukkan } \\
\text { bagaimana ilmu sains } \\
\text { berjalan } \\
\text { pertimbangan } \\
\text { dan dengan } \\
\text { induktif } \\
\end{array}$ & 9 & 4 \\
\hline $\begin{array}{l}\text { Memberikan hubungan } \\
\text { sebab dan akibat. }\end{array}$ & 48 & 23 \\
\hline $\begin{array}{l}\text { Mendiskusikan fakta } \\
\text { dan bukti. }\end{array}$ & 77 & 37 \\
\hline $\begin{array}{l}\text { Menyajikan metode } \\
\text { ilmiah dan pemecahan } \\
\text { masalah. }\end{array}$ & 50 & 24 \\
\hline$\Sigma$ & 210 & 100 \\
\hline
\end{tabular}

Penyajian indikator literasi sains aspek sains sebagai cara berpikir menunjukkan jumlah yang beragam. Indikator yang cukup seing tersaji adalah indikator memberikan hubungan sebab dan akibat; mendiskusikan fakta dan bukti dan menyajikan metode ilmiah dan pemecahan masalah dengan persentase $23 \%, 37 \%$ dan $24 \%$. Sedangkan indikator lainnya tersaji dengan presentase yang kecil yaitu di bawah $5 \%$. 


\section{Pembahasan}

Paul de Hurd dari Stanford University adalah orang yang pertama menggunakan istilah literasi sains. Sekalipun Hurd menekankan pentingnya literasi sains, namun la tidak memberikan definisi spesifik terhadap istilah ini. Menurutnya, science literacy berarti tindakan memahami sains dan mengaplikasikannya bagi kebutuhan masyarakat (Cansiz \& Turker, 2011).

National Science Teacher Assosiation (1971 dalam Sains Edutainment, 2012) yang mengemukakan bahwa seseorang yang memiliki literasi sains adalah orang yang menggunakan konsep sains, mempunyai keterampilan proses sains untuk dapat menilai dalam membuat keputusan sehari-hari ketika berhubungan dengan orang lain, lingkungannya, serta memahami interaksi antara sains, teknologi dan masyarakat, termasuk perkembangan sosial dan ekonomi.

Berdasarkan pernyataan di atas, jelas bahwa literasi sains dapat dikatakan bersifat multidimensional yang sejalan dengan Laugksch bahwa literasi sains tidak hanya pemahaman terhadap konsep dan ide sains, melainkan sifat ilmu pengetahuan dan interaksi ilmu pengetahuan dan masyarakat (dalam Cansiz \& Turker, 2011). Karena itu, literasi sains dapat dikatakan sebagai unsur utama yang diperlukan dalam pendidikan sains dan harus dimiliki oleh setiap individu untuk dapat beradaptasi dengan tuntutan kehidupan di masa mendatang.

Faktor-faktor yang berpengaruh pada peningkatan literasi sains menjadi menarik untuk dipelajari. Salah satunya adalah literasi sains pada buku teks pelajaran. Penelitian sebelumnya melaporkan bahwa sebagian besar guru sains menggunakan buku teks pelajaran untuk sebagian besar waktu pembelajaran mereka. Ini menjadi suatu masalah besar karena hampir sebagian mereka percaya penuh bahwa buku teks memainkan peran utama dalam pembelajaran (Lumpe dan Beck, 1996 dalam Kirk et all, 2001). Hal inilah yang melatarbelakangi analisis terhadap buku teks pelajaran ini penting untuk dilakukan. Fokus dari analisis buku ini adalah menganalisis penyajian aspek sains sebagai berpikir dengan tujuan untuk memperoleh gambaran 
penyajian literasi sains pada buku yang berlaku di kurikulum 2013.

Penelitian literasi sains pada buku teks pelajaran sudah pernah dilakukan sebelumnya. Hasil menunjukkan bahwa sebagian besar buku teks pelajaran yang diteliti masih belum menyeimbangkan proporsi keempat aspek literasi sains. Melainkan lebih sering menyajikan pengetahuan sains atau buku tersebut lebih menekankan pada konten/produk. Fakta ini mungkin menjadi satu alasan rendahnya nilai literasi sains siswa Indonesia yang dilaporkan PISA sejak tahun 2000 hingga 2015. Karena pada nilai yang diperoleh, kemampuan yang dimiliki siswa Indonesia dinilai hanya akan mampu mengingat fakta, istilah, dan hukum-hukum ilmiah serta menggunakannya dalam menarik kesimpulan ilmiah yang sederhana (Yusuf, 2004 dalam Amalia, 2009).

Hasil yang ditemukan pada penelitian kali ini menunjukkan persentase sebesar 21\%. Dengan kata lain, Buku $X$ jarang menyajiakn aspek sains sebagai cara berpikir di dalamnya. Hal ini sejalan dengan hasil penelitian terdahulu (Chiappetta et al., 1993 dalam Amalia, 2009; Chabalengula et al., 2008; Amalia, 2009; Lahiriah, 2008, Nurfaidah, 2014; Nurfaidah, 2017). Adapun penyajian aspek ini, banyak ditemukan pada Tema 1 dan 2 yaitu pada materi Benda-benda di Lingkungan dan Peristiwa dalam Kehidupan. Materi pada tema tersebut cukup banyak memberikan hubungan sebab akibat peristiwa yang terjadi di kehidupan, mendiskusikan fakta dan bukti bagaimana suatu peristiwa bisa terjadi dalam kehidupan dan menyajikan metode ilmiah serta pemecahan masalah dalam kehidupan sehari-hari.

Penelitian terdahulu yang dilakukan Nurfaidah (2014) juga dilakukuan terhadap buku teks kelas V SD. Jika hasilnya kita bandingkan dengan penelitian yang dilakukan kali ini maka sajian literasi sains aspek sains sebagai cara berpikir pada buku tematik yang berlaku pada Kurikulum 2013 telah mengalami peningkatan sebesar $15,2 \%$, yaitu pada buku teks pelajaran IPA Kelas V Kurikulum KTSP sebesar $5,8 \%$ dan $21 \%$ pada buku yang berlaku saat ini. Fakta ini pun selaras dengan laporan PISA 2015 bahwa .skor literasi sains siswa Indonesia lebih besar dibandingkan tahun-tahun sebelumnya, yaitu 403. 
Dengan demikian dapat dikatakan bahwa buku teks pelajaran yang memuat aspek literasi sains berpengaruh terhadap pengembangan kompetensi dan peningkatan literasi sains siswa.

Sekalipun muatan aspek sains sebagai cara berpikir pada buku yang berlaku saat ini telah mengalami peningkatan. Namun, Indonesia masih memiliki tugas yang cukup berat untuk bersaing di dunia global. Karena skor hasil PISA yang didapat masih jauh dari skor rata-rata Internasional sebesar 493. Karena itulah Indonesia masih berada pada peringkat yang rendah. Sehingga seluruh aspek pembelajaran yang bermuatan literasi sains masih harus terus dikembangkan, termasuk salah satunya adalah buku teks pembelajaran, sebagai upaya meningkatkan kemampuan literasi sains siswa Indonesia.

Berdasarkan hal terbut, buku ini masih membutuhkan penekanan dalam menyajikan keempat aspek literasi sains. Terutama penekanan pada komponen proses dan konteks. Agar masyarakat Indonesia tidak sekedar menjadi pemerhati dan pengguna ilmu pengetahuan dan teknologi. Hal ini sejalan dengan Cansiz \& Turker (2011) yang menyatakan bahwa dengan menekankan semua aspek literasi sains, akan mempersiapkan potensi warga yang melek sains untuk kemajuan bangsa dan pemerintahan yang lebih lebih cocok terhadap perubahan global yang sangat cepat.

\section{E. Kesimpulan}

Aspek sains sebagai cara berpikir masih jarang disajikan pada buku $Y$ yaitu sebesar 21\%. Namun jika dibandingkan dengan hasil analisis pada buku KTSP sebelumnya, penyajian aspek ini sudah mengalami peningkatan sebesar 15,2\%. Adapun aspek ini disajikan pada seluruh tema buku tersebut dengan nilai yang beragam. Pada tema 1 dan 2 aspek ini paling sering disajiakan yaitu sebesar $71 \%$, dan $51 \%$. Temuan ini menunjukkan bahwa buku $Y$ sudah cukup menekankan materi yang menunjang pada penguasaan proses sains.

Saran bagi penelitian selanjutnya dapat dilakukan untuk memperluas gambaran literasi sains dalam segala aspek pembelajaran khususnya buku teks pelajaran, yaitu dengan menentukan hubungan antara 
buku teks pelajaran tersebut dengan tingkat literasi sains siswa secara langsung dan menentukan hubungan antara materi pembelajaran dengan penyajian aspek literasi sains.

\section{DAFTAR PUSTAKA}

Amalia, Suci. (2009). Analisis Buku Ajar Biologi SMP Kelas VIII di Kota Bandung Berdasarkan Literasi Sains. Skripsi: Tidak diterbitkan

Cansiz \& Turker. (2011). Scientific Literacy Investigation in Science Curricula: The Case of Turkey. Journal of Educational Science. ISSN 130-8971

Chabalengula, Lorsbach, Mumba, Moore. (2008). Curriculum and Instructional Validity of Scientific Literacy Themes Covered in Zambian High School Biologi Curriculum. International Journal of Environmental \& Science Education. 3, (4), 207-220

Departemen Pendidikan Nasional. (2008). Permendiknas Nomor 2 Tahun 2008 Tentang Buku. Jakarta: Departemen Pendidikan Nasional.

Erdoğan \& Köseoğlu. (2012). Analysis of High School Physics, Chemistry and Biology Curriculum in term of Scientific Literacy Themes. Educational Science: Theori \& Practice. 12(4), 2899-2904.
Firman, H. (2007). Analisis Literasi Sains Berdasarkan Hasil PISA Nasional Tahun 2006. Jakarta: Pusat Penilaian Pendidikan Balitbang Depdiknas.

Gurria, A. (2013). PISA 2012 Results in Focus. Turki: OECD. [online]. Tersedia:

https://www.oecd.org/pisa/pisa -2012-results-in-focus.pdf

Gurria, A. (2016). PISA 2012 Results in Focus. Turki: OECD. [online]. Tersedia:

https://www.oecd.org/pisa/pisa -2015-results-in-focus.pdf

Kirk, M., Matthews, C. \& Kurtts, S. (2001). The Trouble with Textbooks. The Science Teacher, 68 (9), 42 -45.

Kompas.com dengan judul "Daftar Lengkap Skor PISA 2018: Kemampuan Baca, Berapa Skor Indonesia?",

https://edukasi.kompas.com/rea d/2019/12/07/09141971/dafta r-lengkap-skor-pisa-2018kemampuan-baca-berapaskorindonesia?page=all. Penulis : Yohanes Enggar Harususilo, Editor

Yohanes Enggar Harususilo, di posting, 19/01/2020. Pk.16.37 wib.

Lahiriah, R.S. (2008). Analisis Buku Ajar Biologi SMA Kelas X di Kota Bandung Berdasarkan Literasi Sains. Skripsi: Tidak diterbitkan

Litbang. (2011). Survei Internasional PISA. Jakarta: KemdikbudNurfaidah, S.S. (2014). Identifikasi Penyajian Aspek Literasi Sains Buku Teks Pelajaran IPA Kelas V SD. Tesis: Tidak diterbitkan

Nurfaidah, S.S. (2014). Identifikasi Penyajian Aspek Literasi Sains Buku Teks Pelajaran IPA Kelas V SD. Tesis: Tidak diterbitkan 
Nurfaidah, S. S. (2017). Analisis Aspek Literasi Sains Pada Buku Teks Pelajaran IPA Kelas V SD. Mimbar Sekolah Dasar, 4(1), 5666.

http://doi.org/10.23819/mimbarsd.v4i1.5585.

Riadiyani, E. (2009). Analisis Buku Ajar Biologi SMA Kelas XI di Kota Bandung Berdasarkan Literasi Sains. Skripsi: Tidak diterbitkan

Rusyati, L. (2009). Analisis Buku Ajar Biologi SMP Kelas VII di Kota Bandung Berdasarkan Literasi Sains. Skripsi: Tidak diterbitkan Sandi, M. (2013). Analisis Buku Ajar Fisika SMA Kelas $X$ di Kota Bandung Berdasarkan Literasi Sains. Skripsi: Tidak diterbitkan

Sains Edutainment. (2012). Definisi Literasi Sains. [online]. Tersedia:

http://sainsedutainment.blogsp ot.com/2012/12/definisiliterasi-sains 23.html. (28 Juni 2013)

Utami, A. A. (2008). Analisis Buku Ajar Biologi SMA Kelas XII di Kota Bandung Berdasarkan Literasi Sains. Skripsi: Tidak diterbitkan 